\title{
The nucleoside-specific Tsx channel from the outer membrane of Salmonella typhimurium, Klebsiella pneumoniae and Enterobacter aerogenes: functional characterization and DNA sequence analysis of the tsx genes
}

\author{
Annette Nieweg ${ }^{1} \dagger$ and Erhard Bremer ${ }^{1,2}$ \\ Author for correspondence: Erhard Bremer. Tel: +496421 281529. Fax: +496421288979. \\ e-mail: bremer@mailer.uni-marburg.de
}

1 Department of Biology, University of Konstanz, PO Box 5560, D-78434 Konstanz, Germany

2 Philipps University Marburg, Laboratory for Microbiology, Karl-vonFrisch Str., D-35032 Marburg, Germany
The Escherichia coli tsx gene encodes an integral outer-membrane protein (Tsx) that functions as a substrate-specific channel for deoxynucleosides and the antibiotic albicidin, and also serves as a receptor for bacteriophages and colicins. We cloned the structural genes of the Tsx proteins from Salmonella typhimurium, Klebsiella pneumoniae and Enterobacter aerogenes and expressed them in an E. coli tsx mutant. The heterologous Tsx proteins fully substituted the $E$. coli $T s x$ protein with respect to its function in deoxynucleoside and albicidin uptake, and as receptor for colicin $K$. The TsX proteins from $K$. pneumoniae and Ent. aerogenes were also proficient as receptors for several Tsx-specific bacteriophages, whereas the corresponding protein from S. typhimurium did not confer sensitivity against these phages. The nucleotide sequence of the tsx genes from $S$. typhimurium, $K$. pneumoniae and Ent. aerogenes was established. Each of the Tsx proteins is initially synthesized with typical bacterial signal sequence peptides and the predicted mature forms of the Tsx proteins have a calculated $M_{r}$ of 30567 (265 residues), 31412 (272 residues) and 31477 (272 residues), respectively. Multiple sequence alignments between the Tsx proteins showed a high degree of sequence identity and revealed the presence of four hypervariable regions, which are thought to constitute segments of the polypeptide chain exposed at the cell surface. Most notable was a deletion of 8 amino acids in one of these hypervariable domains in the 5 . typhimurium Tsx protein. When this deletion was introduced by site-directed mutagenesis into the corresponding region of the $E$. coli tsx gene, the mutant Tsx-515 protein lost its phage receptor function but still served as a colicin $K$ receptor and as a substrate-specific channel, indicating that the region between residues 198 and 207 might be part of the bacteriophage receptor area. Multiple sequence alignments, structural predictions and the properties of previously characterized Tsx missense mutants were taken into account to develop a two-dimensional model for the topological organization of the Tsx protein within the outer membrane.

Keywords: transport, colicins, bacteriophages, albicidin, membrane proteins

†Present address: Department of Biochemistry and Microbiology, University of Victoria, Victoria, British Columbia V8W 3P6, Canada.

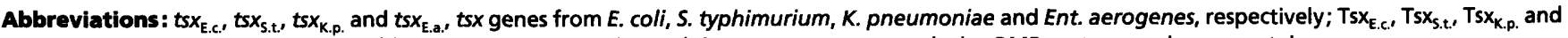
$\mathrm{TSX}_{\mathrm{E} . \mathrm{a}, \mathrm{r}}$ Tsx proteins from $E$. coli, $S$. typhimurium, $K$. pneumoniae and $E n t$. aerogenes, respectively; OMP, outer-membrane protein.

The GenBank accession numbers for nucleotide sequences of the $S$. typhimurium, K. pneumoniae and Ent. aerogenes tsx genes are Z26657, Z26656 and Z26655, respectively. 


\section{INTRODUCTION}

The outer membrane of Gram-negative bacteria functions as a permeability barrier against toxic compounds and serves as a molecular filter for hydrophilic substances. Substrate permeation across this membrane occurs by several mechanisms (Benz, 1994; Nikaido, 1994). The transport of iron-chelator complexes and vitamin $B_{12}$ depends on highly specific receptor proteins, and the release of these substrates into the periplasm requires the energy-coupling function of $\mathrm{Ton} B$, a protein anchored in the cytoplasmic membrane (Killmann et al., 1993). In contrast, a large variety of molecules can passively diffuse into the periplasmic space through general porins such as $\mathrm{OmpC}, \mathrm{OmpF}$ and $\mathrm{PhoE}$, which form open, water-filled pores that function independently of TonB (Cowan et al., 1992; Kreusch \& Schulz, 1994; Weiss et al., 1991). At low external concentrations, certain compounds permeate the outer membrane via substrate-specific channels. Like the non-specific porins, these channels are water-filled and function independently of TonB (Schirmer et al., 1995). However, they contain a saturable substrate-binding site that endows them with specific characteristics. This ligand-binding site permits the efficient flux of substrate through the channel at exceedingly low external substrate concentration, but when saturated, it limits the rate of solute diffusion. Consequently, substrate-specific channels are of particular physiological importance for the bacterial cell in an environment with a low nutrient content where the flux of substrate through general porins is inefficient (Benz, 1994; Nikaido, 1994).

The Escherichia coli $\mathrm{Tsx}$ protein (Tsx $\mathrm{E}_{\mathrm{E} . \mathrm{c}}$ ) is an example of such a substrate-specific channel. The 272-residue Tsx protein (Bremer et al., 1990) is a minor component of the E. coli outer membrane (Bremer et al., 1988; Krieger-Brauer \& Braun, 1980), but it is essential for the uptake of deoxynucleosides and nucleosides at submicromolar substrate concentrations (Fsihi et al., 1993; Hantke, 1976; Krieger-Brauer \& Braun, 1980). Reconstitution of the purified Tsx protein into artificial membranes has proven that it is a channel-forming protein and that its substrate specificity results from a stereo-specific ligand-binding site inside the channel (Benz et al., 1988; Maier et al., 1988). Nucleosides and deoxynucleosides are abundant in many habitats, and $E$. coli can effectively use these compounds both as carbon and nitrogen sources and as precursors for the synthesis of nucleic acids (Zalkin \& Nygaard, 1996). Consequently, the Tsx protein enables the bacterial cell to efficiently scavenge these versatile substrates from the environment. The function of the Tsx protein as a nucleoside-specific channel is reflected by the co-regulation of its structural gene (tsx) (Bremer et al., 1988; Krieger-Brauer \& Braun, 1980) with a set of genes encoding transporters necessary for nucleoside translocation across the cytoplasmic membrane and enzymes required for their intracellular metabolism (ValentinHansen et al., 1996; Zalkin \& Nygaard, 1996). Expression of the $E$. coli $t s x$ gene $\left(t s x_{\text {E.c. }}\right)$ is mediated by two differently regulated promoters; it is under double- negative control by the DeoR and CytR repressors and is positively affected by the cAMP/CRP receptor protein complex (Bremer et al., 1990; Gerlach et al., 1991).

The Tsx protein renders the $E$. coli cell susceptible to substances and agents that are detrimental to cell growth. The antibiotic albicidin, a potent inhibitor of prokaryotic DNA replication, uses the Tsx channel for its efficient permeation across the outer membrane (Birch et al., 1990; Fsihi et al., 1993). In addition, the Tsx protein functions as receptor for several lytic bacteriophages and colicins (Bradley \& Howard, 1992; Maier et al., 1990; Manning \& Reeves, 1978; Pilsl \& Braun, 1995; Schneider et al., 1993). To further aid the genetic and biochemical characterization of the multifunctional Tsx protein, we have cloned and sequenced the $t s x$ genes from Salmonella typhimurium, Klebsiella pneumoniae and Enterobacter aerogenes ( $t s x_{\mathrm{S} . t .}, t s x_{\mathrm{K} . \mathrm{p} .}$ and $t s x_{\mathrm{E} . \mathrm{a}}$. respectively). We report here that these $t s x$ genes can be efficiently expressed in an $E$. coli host, and we have studied the properties of the heterologous Tsx proteins with respect to their function in nucleoside and albicidin uptake and as bacteriophage and colicin receptors. By combining tools for structural predictions of poreforming outer-membrane proteins (OMPs) and multiple sequence alignments, we have developed a model for the topology of the Tsx protein and we discuss here its implications for the function of this integral membrane protein.

\section{METHODS}

Bacterial strains, plasmids and bacteriophages. The $E$. coli $\mathrm{K}$ 12 strains used in this study are listed in Table 1 . The $E$. coli strain AN1 ( $t s x \operatorname{rec} A$ ) was employed in most experiments as the host strain for the cloned $t s x_{\text {s.t. }}, t s x_{\text {K.p. }}$ and $t s x_{\text {E.a. }}$ genes. It was constructed by $\mathrm{P} 1$ vir-mediated transduction of the recA56 mutation from strain GE1806 into BRE2070 (tsx) (Table 1) by using a tightly linked $s r l:: \operatorname{Tn} 10$ insertion as the selective marker. Co-transduction of the recA56 and srl::Tn10 mutations was confirmed by testing tetracycline-resistant transductants for sensitivity against UV radiation. Strain HF1 $\left(\right.$ met $^{+}$ $\left.i l v^{+} v a l^{R}\right)$ (Table 1) was used as the host for $t s x^{+}$plasmids when the susceptibility of strains against a crude preparation of the antibiotic albicidin was tested; HF1 is resistant against the excess of valine synthesized by the albicidin producer Xanthomonas albilineans strain LS155 (Birch et al., 1990; Fsihi et al., 1993). Strain HF1 harbouring the various $t s x^{+}$plasmids was also used for measuring $8-\left[{ }^{14} \mathrm{C}\right]$ deoxyadenosine uptake. $K$. pneumoniae KAY2026 $\left(\mathrm{F}^{-}\right.$arg gua $\left.\mathrm{P}^{\mathrm{s}}\right)$, S. typhimurium LT2 and Ent. aerogenes (ATCC 13048) were used as sources for chromosomal DNA to clone the $t s x$ genes. These strains have been described by Dahl et al. (1989) and by Sprenger \& Lengeler (1984), and were kindly provided by J. Lengeler (University of Osnabrück, Germany) and M. Dahl (University of Erlangen-Nürnberg, Germany). The albicidin producer X. albilineans LS155 (Birch et al., 1990) was obtained from R. Birch (University of Queensland, Australia).

Plasmid pTX5 is a pBR322 derivative and carries the E. coli $t s x^{+}$gene on a chromosomal ClaI-StuI restriction fragment (Bremer et al., 1990). Plasmid pTX5- $\Delta 1(t s x-515)$ is a derivative of pTX5 and was constructed in the course of this study by introducing into the $t s x$ gene via site-directed mutagenesis a $24 \mathrm{bp}$ deletion that removes residues Ser-199 to Ile-206 from the $\mathrm{Tsx}_{\mathrm{E.c.}}$ protein. Plasmid pHF1 carries the E. coli ts $x^{+}$gene 
Table 1. Bacterial strains derived from E. coli K-12

\begin{tabular}{|c|c|c|}
\hline Strain & Description/genotype & Source/reference \\
\hline MC4100 & $\begin{array}{l}\operatorname{araD-139} \Delta(\operatorname{argF}-\mathrm{lac}) U 169 \text { deoC-1 flbB-5301 relA-1 } \\
\text { rpsL-150 ptsF-25 rbsR }\end{array}$ & Casadaban (1976) \\
\hline BRE2000 & MC4100 ts $x:: \operatorname{Tn} 10$ & Gerlach et al. (1991) \\
\hline BRE2050 & metB ilv rpsL $\Delta(\operatorname{argF}-$ lac $) U 169$ cytR-9 deoR-8 & Bremer et al. (1988) \\
\hline BRE2070 & BRE2050 ts $x$ & Bremer et al. (1988) \\
\hline AN1 & BRE2070 recA-56 srl:: $\operatorname{Tn} 10$ & This study \\
\hline GE1806 & Hfr KL16 recA-56 srl:: Tn10 & $\begin{array}{l}\text { G. Weinstock (Texas, } \\
\text { USA) }\end{array}$ \\
\hline HF1 & BRE2070 met $^{+} i l v^{+} v a l^{\mathbf{R}} \lambda \mathrm{p} 1048\left(t y r T-l a c \mathrm{Y}^{+}\right)$ & Fsihi et al. (1993) \\
\hline TG1 & 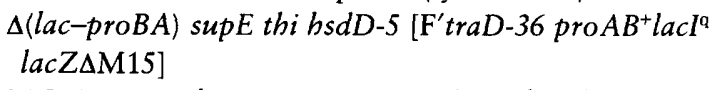 & Carter et al. (1985) \\
\hline DHB4 mutS & MC4100 $\Delta($ malF $) 3$ mutS: :Tn10 $\left[\mathrm{F}^{\prime}\right.$ pro lac $\left.\left(\operatorname{lac}^{q}\right)\right]$ & $\begin{array}{l}\text { M. Ehrmann (Konstanz, } \\
\text { Germany) }\end{array}$ \\
\hline K49 & pColK-K49; colicin K producer & Hantke (1976) \\
\hline
\end{tabular}

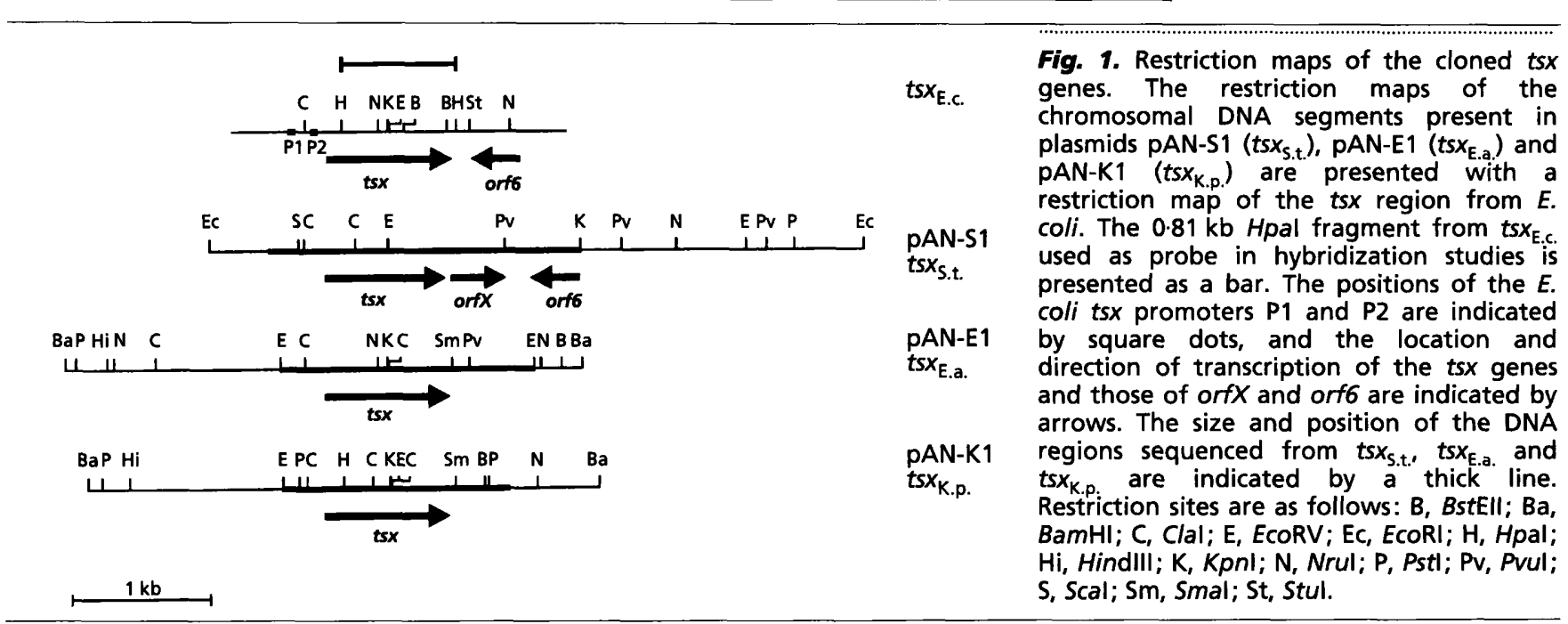

(Fsihi et al., 1993) and is a derivative of the low-copy-number plasmid pHSG575 (Takeshita et al., 1987). Plasmids pAN-S1, pAN-K1 and pAN-E1 are also based on the pHSG575 replicon and carry the $t s x^{+}$genes of $S$. typhimurium, K. pneumoniae and Ent. aerogenes on chromosomal EcoRI or BamHI restriction fragments (Fig. 1). A 24 bp DNA segment was introduced by site-directed mutagenesis into pAN-S1 ( $\left.t s x_{\text {s.t. }}\right)$, yielding pAN-S1::1 (ts $x-520)$; this plasmid encodes a mutant $\mathrm{Tsx}_{\text {s.t. }}$ protein with 8 additional amino acids between residues Asp-199 and Pro-200. The sources of the Tsx- (T6, T6h3.1, $\mathrm{Ox} 1, \mathrm{H} 1, \mathrm{H} 3, \mathrm{H} 8, \mathrm{~K} 9$ and K18), OmpA- (TuII*) and LamBspecific (ivir) bacteriophages have been described by Maier et al. (1990) and Schneider et al. (1993). The bacteriophage $\lambda$ cloning vectors $\lambda S E 6$ (Elledge \& Walker, 1985) and igt10 (Huynh et al., 1985) were used to construct gene libraries from S. typhimurium, K. pneumoniae and Ent. aerogenes. Recombinant derivatives of phages M13mp18, M13mp19, M13BM20 and M13BM21 (Boehringer) were used for the preparation of template DNA for the nucleotide sequence analysis of $t s x$.

Media, growth conditions and genetic procedures. E. coli, $S$. typhimurium, K. pneumoniae and Ent. aerogenes strains were grown aerobically at $37^{\circ} \mathrm{C}$ in rich media (LB or DYT) or minimal medium A (MMA) with $0.2 \%$ glycerol as the carbon source (Miller, 1992; Sambrook et al., 1989). X. albilineans LS155 was grown at $28^{\circ} \mathrm{C}$ in SP medium (Birch et al., 1990; Fsihi et al., 1993). Tetracycline, kanamycin, chloramphenicol and ampicillin were added to liquid and solid media at a concentration of $5,30,30$ and $50 \mu \mathrm{g} \mathrm{ml}^{-1}$, respectively. Standard techniques were used for the propagation of bacteria and bacteriophages and for general transduction with phage P1vir. Recombinant M13 phages were propagated on strain TG1 (Table 1).

Colicin K, albicidin and phage susceptibilities. Sensitivity of E. coli strains to Tsx-, OmpA- and LamB-specific phages was determined either by cross-streaking the bacterial colonies against high-titred phage lysates on LB plates or by plating aliquots of 10 -fold dilutions of the phage lysates onto bacterial cell lawns seeded in LB soft agar. A crude preparation of colicin $\mathrm{K}$ was prepared from strain K49 (Table 1) after mitomycin $\mathrm{C}$ induction. The sensitivity of bacterial strains against colicin $\mathrm{K}$ was assayed by spotting $10 \mu \mathrm{l}$ aliquots of a series of twofold dilutions of the colicin $\mathrm{K}$ preparation onto bacterial cell lawns plated in LB soft agar. Sensitivity to colicin $\mathrm{K}$ was recorded after incubation of the plates at $37^{\circ} \mathrm{C}$ overnight (Krieger-Brauer \& Braun, 1980). The antibiotic albicidin was partially purified from the supernatant of cultures of $X$. albilineans LS155 by adsorption to Amberlit 
(a)

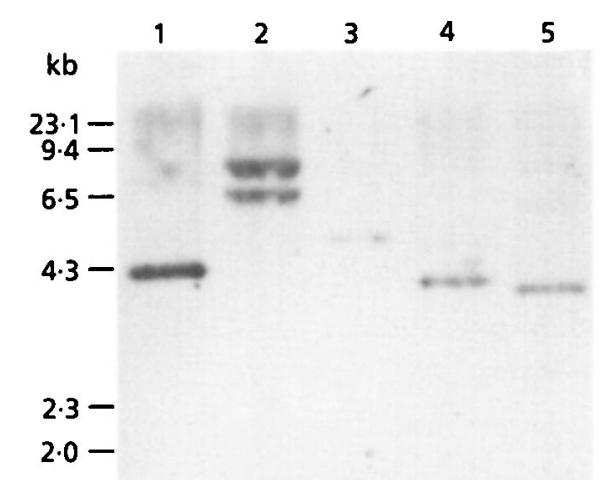

(b)

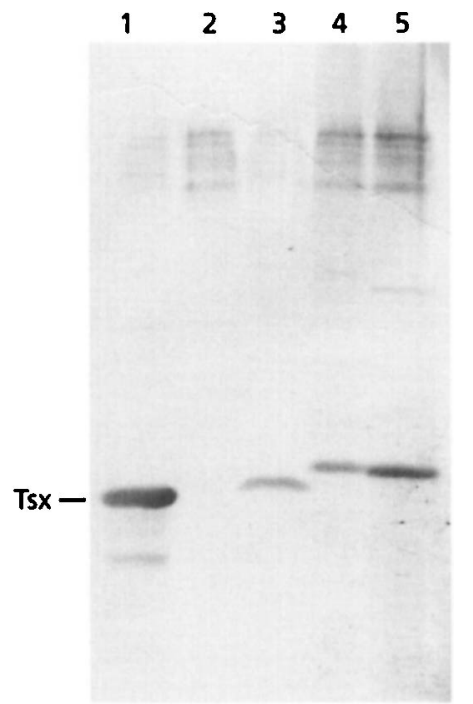

Fig. 2. Detection of the tsx genes and Tsx proteins from $S$. typhimurium, $K$. pneumoniae and Ent. aerogenes. (a) Chromosomal DNA from $E$. coli MC4100 $\left(t s x^{+}\right)$(lane 1), E. coli BRE2000 (tsx::Tn10) (lane 2), S. typhimurium (lane 3), Ent. aerogenes (lane 4 ) and $K$. pneumoniae (lane 5) was digested with either Clal (lanes 1 and 2), EcoRI (lane 3) or BamHI (lanes 4 and 5). The resulting restriction fragments were electrophoretically separated on an agarose gel and transferred onto a nylon membrane. The bound DNA fragments were then hybridized against a $0.81 \mathrm{~kb} \mathrm{Hpal} \mathrm{fragment}$ from $t s x_{E C}$. (b) The cell envelope proteins from $E$. coli BRE2050 (tsx $x^{+}$) (lane 1), E. coli BRE2070 (tsx) (lane 2), S. typhimurium (lane 3), Ent. aerogenes (lane 4) and $K$. pneumoniae (lane 5) were separated by SDSPAGE. The proteins were electrophoretically transferred onto a nylon membrane, and the bound proteins were then reacted with an antiserum directed against Tsx $_{\text {E.c. }}$.
XAD-7 resin (Sigma) and subsequent elution with methanol (Birch et al., 1990; Fsihi et al., 1993). The susceptibility of E. coli strains to albicidin was determined by placing $50 \mu \mathrm{l}$ aliquots of twofold dilutions of the albicidin solution into wells $(0.5 \mathrm{~cm})$ cut into LB agar plates overlaid with soft agar containing the bacterial cells. The zone of growth inhibition around the wells was recorded after overnight growth of the cells at $37^{\circ} \mathrm{C}$ (Fsihi et al., 1993).

Nucleic acid procedures and cloning of the tsx genes from $S$. typhimurium, $K$. pneumoniae and Ent. aerogenes. Isolation and routine manipulations of plasmid, chromosomal and $\lambda$ DNA were all carried out by standard techniques (Sambrook et al., 1989). To detect the $t s x$ genes in the chromosomal DNA of S. typhimurium, K. pneumoniae and Ent. aerogenes, we performed Southern hybridization experiments (Sambrook et al., 1989) using a $0.81 \mathrm{~kb} \mathrm{Hpal} \mathrm{fragment} \mathrm{from} \mathrm{pTX5} \mathrm{carrying}$ most of the $E$. coli ts $x$ coding region (Fig. 1) as the hybridization probe. The probe was labelled with digoxygenin, and the DNA : DNA hybrids were detected according to the procedures provided with the Non-radioactive DNA Labelling and Detection Kit (Boehringer). Chromosomal DNA from S. typhimurium, K. pneumoniae and Ent. aerogenes was digested with EcoRI, BamHI and BamHI, respectively. The resulting restriction fragments were then electrophoretically separated on a $0.8 \%$ agarose gel, transferred onto a nylon membrane $(\mathrm{Ny} 13 \mathrm{~N}$; pore size $0.45 \mu \mathrm{m}$; Schleicher \& Schuell), and hybridized to the $t s x_{\text {E.c. }}$ DNA probe. The hybridization conditions were as follows. The prehybridization of the nylon membrane was performed at $68^{\circ} \mathrm{C}$ and was followed by a temperature down-shift to $45^{\circ} \mathrm{C}$ for the period of hybridization to the DNA probe. After incubation overnight in the hybridization solution, the membrane was washed twice for $5 \mathrm{~min}$ at room temperature with a solution containing $2 \times \operatorname{SSC}, 0 \cdot 1 \%(\mathrm{w} / \mathrm{v}) \mathrm{SDS}$ and twice for $15 \mathrm{~min}$ at $45^{\circ} \mathrm{C}$ with a solution containing $0.5 \times \mathrm{SSC}, 0.1 \%$ $(w / v)$ SDS. We found that the DNA sequences homologous to $t s x_{\text {E.c }}$ were located on $4.7 \mathrm{~kb}$ EcoRI, $4.0 \mathrm{~kb}$ BamHI and $4.2 \mathrm{~kb}$ $B a m \mathrm{HI}$ restriction fragments within the S. typhimurium, $K$. pneumoniae and Ent. aerogenes genomes, respectively (Fig. 2). To clone these DNA fragments, we digested chromosomal DNA from these bacteria with restriction enzymes, electrophoretically separated the restriction fragments on agarose gels and eluted DNA fragments of the appropriate size from gel slices. The EcoRI restriction fragments from $S$. typhimurium were ligated into the $\lambda$ cloning vector $\lambda$ gt 10 (Huynh et al., 1985) and the BamHI fragments from K. pneumoniae and Ent. aerogenes were cloned into the $\lambda$ SE6 vector (Elledge \& Walker, 1985). The recombinant $\lambda$ DNA was packed in vitro with Gigapack II Gold Packaging extracts (Stratagene) and the bacteriophages were plated on strain BRE2000 (tsx::Tn10) (Table 1). Recombinant $\lambda$ phages carrying the $t s x$ regions were identified by plaque hybridization using the digoxygeninlabelled $H p a I$ restriction fragment from the $t s x_{\text {E.c. }}$ gene (Fig. 1) as probe. The cloned DNA fragments from positively reacting phages were cut with restriction enzymes from the recombinant $\lambda$ DNA and inserted into the polylinker of the chloramphenicol-resistant low-copy-number vector pHSG575 (Takeshita et al., 1987). These constructions yielded plasmids pAN-S1 (ts $\left.x_{\text {s.t. }}\right)$, pAN-K1 (ts $\left.x_{\text {K.p. }}\right)$ and pAN-E1 $\left(t s x_{\text {E.z. }}\right)$, respectively (Fig. 1). The position and orientation of the $t s x$ genes within the cloned DNA segments was established by probing various single and multiple restriction digests of the plasmids with digoxygenin-labelled DNA hybridization probes derived from plasmid pTX5. These DNA probes carried either the $5^{\prime}$ region of $t s x_{\mathrm{E} . \mathrm{c}}$ on a $0.6 \mathrm{~kb}$ ClaI-KpnI restriction fragment or the $3^{\prime}$ region on a $0.48 \mathrm{~kb} \mathrm{KpnI-HpaI}$ fragment (Fig. 1).

For the DNA sequence analysis of $t s x_{\mathrm{S} . t .}, t s x_{\text {E.a. }}$ and $t s x_{\mathrm{K} . \mathrm{p} .}$ and their flanking regions, we isolated a series of subclones from plasmids pAN-S1, pAN-E1 and pAN-K1 (Fig. 1) in bacteriophage M13 cloning vehicles and used these recombinant phages to construct a series of overlapping M13 clones with defined deletions (Dale et al., 1985). The sequencing (Sanger et al., 1977) of double- or single-stranded DNA segments was performed with the Sequenase $2.0 \mathrm{Kit}$ (USB) under conditions recommended by the suppliers. Gaps in the sequence were closed by using several synthetic oligonucleotide primers. The entire DNA sequence of each $t s x$ gene was determined on both DNA strands.

Site-directed mutagenesis of the $t s x_{E . c .}$ and $t s x_{\text {s.t. }}$. For the deletion of $24 \mathrm{bp}$ in the $E$. coli ts $x$ gene and for the insertion of these $24 \mathrm{bp}$ in the corresponding segment in $t s x_{\text {s.t. }}$, we used site-directed mutagenesis (Deng \& Nickoloff, 1992) and 
reagents from the Transformer Site-Directed Mutagenesis Kit (Clontech). This procedure uses double-stranded plasmid DNA as a template. The plasmid must contain a unique restriction site and a selectable antibiotic resistance marker. In addition to the mutagenic oligonucleotide, a selection oligonucleotide is used that contains a mutation in the restriction enzyme recognition site that is unique in the target plasmid. The mutagenesis was performed on the E. coli $t s x^{+}$plasmid pTX 5 to delete 24 bp between nucleotides 661 and 684 within the $t s x$ gene. The mutagenic primer M1 ( $5^{\prime}$ CCGATTTAGGGGATGAC- $\triangle$-AAGACCCGTACTAATAACTCTATCGC $3^{\prime}$ ) anneals to 17 bp upstream and 26 bp downstream of the region in the ts $x$ gene that is to be deleted. The selection primer S1 (5' CGTCTTCAAGATATCTCATGTTTGAC 3') changes the unique EcoRI site (GAATTC) of pTX5 (Bremer $e t$ al., 1990) into a recognition sequence for EcoRV (GATATC). Conversely, the $24 \mathrm{bp}$ segment of $t s x_{\text {E.c. }}$ was introduced after nucleotide position $663 \mathrm{bp}$ into $t s x_{\mathrm{s} . t}$ carried by plasmid pAN$\mathrm{S} 1$. In the mutagenic primer M2 (5' GGATCTGATTTAGGCGACGAT::AGCGGTAACGCAATCAACGGTATT:: CCGAACCGTACCAGCAACTCC $3^{\prime}$ ), the 24 nucleotides to be inserted are flanked on both sides by 21 nucleotides that are complementary to the nucleotide sequence of $t s x_{\mathrm{s} . t .}$. The selection primer S2 ( $5^{\prime}$ GCAGGTCGACGGTACCCCGGGAATTCG 3') alters the single restriction site for $\mathrm{BamHI}$ (GGATCC) in pAN-S1 to a KpnI site (GGTACC). The mutagenized plasmids were transformed into strain DHB4 mutS (Table 1) and the presence of the desired deletion and insertion mutations was verified by DNA sequence analysis. These manipulations yielded plasmids pTX5- $\Delta 1$ with the mutant $(t s x-515) t s x_{\text {E.c. }}$ and plasmid pAN-S1::1 with the mutant $(t s x-520) t s x_{\text {s.t. }}$.

Preparation of cell envelopes, gel electrophoresis, immunological detection of the Tsx protein and nucleoside uptake assays. Cell envelopes were prepared from $40 \mathrm{ml}$ overnight cultures grown in DYT medium. The membrane proteins were solubilized in sample buffer containing $2 \%$ SDS by boiling for $5 \mathrm{~min}$ and portions were electrophoresed on a $12 \%$ SDS-polyacrylamide gel (Bremer et al., 1988). Protein bands were visualized by staining with Coomassie brilliant blue. For the immunological detection of the Tsx protein, electrophoretically separated cell envelope proteins were transferred to a nylon membrane (Immobilon-P; pore size $0.45 \mu \mathrm{m}$; Millipore) and reacted with a rabbit antiserum raised against denatured $T s x_{\text {E.c. }}$. The antigen-antibody complexes were visualized with a second goat anti-rabbit immunoglobulin $G$ alkaline-phosphatase-conjugated antibody using 5-bromo-4chloro-3-indolylphosphate and nitroblue-tetrazolium chloride as substrates (Bremer et al., 1988). The initial uptake of 8$\left.{ }^{14} \mathrm{C}\right]$ deoxyadenosine $\left[46.6 \mathrm{mCi} \mathrm{mmol}^{-1}\left(1.72 \mathrm{GBq} \mathrm{mmol}^{-1}\right)\right.$; Du Pont-New England Nuclear] was measured in cells grown in MMA with $0.2 \%$ glycerol as the carbon source, as described previously (Fsihi et al., 1993; Krieger-Brauer \& Braun, 1980). The final substrate concentration of $8-\left[{ }^{14} \mathrm{C}\right]$ deoxyadenosine in the transport assays was $0.55 \mu \mathrm{M}$.

DNA and amino acid sequence analysis. DNA and protein sequences were assembled and analysed with the Lasergene program (DNASTAR) on an Apple Macintosh computer. Searches for homologies were performed at the National Center for Biotechnology Information with the BLAST programs (Altschul et al., 1990). The analysis of the Tsx sequences from E. coli, S. typhimurium, K. pneumoniae and Ent. aerogenes and the prediction of the membrane topology of Tsx were performed with computer programs developed by F. Pattus and co-workers (Jeanteur et al., 1991, 1994) for the alignment and analysis of the transmembrane topology of bacterial porins. In general, $\beta$-strands were predicted using a combination of hydrophobicity and hydrophobic moment values in conjunction with sequence conservation, absence of gaps in the aligned protein sequences and absence of turn predictions. Extramembranous domains were defined by their low hydrophobicity and hydrophobic moment values, sequence variability, the presence of gaps and turn predictions.

\section{RESULTS AND DISCUSSION}

\section{S. typhimurium, K. pneumoniae and Ent. aerogenes synthesize an OMP related to $\mathrm{TsX}_{\mathrm{E}, \mathrm{c} .}$}

To investigate whether S. typhimurium, K. pneumoniae and Ent. aerogenes possess DNA sequences related to $t s x_{\text {E.c., }}$ we probed restriction digests of total chromosomal DNA from these Gram-negative bacteria with a labelled $H p a I$ fragment carrying most of the $t s x$ coding region (Fig. 1). This probe hybridized specifically to a $4.2 \mathrm{~kb}$ ClaI DNA fragment in a restriction digest of genomic DNA prepared from the $E$. coli $t s x^{+}$strain MC4100 and to two ClaI fragments when the chromosomal DNA was prepared from the $t s x:: \operatorname{Tn} 10$ mutant strain BRE2000 (Fig. 2). Such a hybridization pattern is expected from the known physical organization of the $t s x_{\text {E.c. }}$ region (Bremer et al., 1990) and the presence of a unique ClaI site in the Tn10 element (Way et al., 1984). We found that the $t s x_{\text {E.c. }}$ DNA probe hybridized to unique genomic restriction fragments from $S$. typhimurium, K. pneumoniae and Ent. aerogenes (Fig. 2). These $t s x$-like genes are apparently expressed, since we detected an OMP that was immunologically related to $\mathrm{Tsx}_{\text {E.c. }}$ in cell envelope preparations from these microorganisms (Fig. 2). Taken together, these observations indicated that S. typhimurium, K. pneumoniae and Ent. aerogenes each possess a tsx gene whose product is routed into the cell envelope.

\section{Cloning and expression of $t s x_{\text {s.t. }}, t s x_{K . p .}$ and $t s x_{E . . a .}$ in E. coli}

To clone these ts $x$ genes, we constructed gene libraries from S. typhimurium, K. pneumoniae and Ent. aerogenes in bacteriophage $\lambda$ cloning vectors. We then searched for the heterologous $t s x$ genes by DNA hybridization in phage plaques using a restriction fragment from $t s x_{E . c .}$ as probe. Positively reacting recombinant $\lambda$ phages were readily detected in each case and the cloned chromosomal DNA segments were subsequently ligated into the low-copy-number vector pHSG575 (Takeshita et al., 1987). These constructions yielded plasmids pAN-S1, pAN-K1 and pAN-E1, carrying $t s x_{\text {S.t. }}, t s x_{\mathrm{K} . \mathrm{p} .}$ and $t s x_{\mathrm{E.a.}}$, respectively. Restriction maps of the cloned DNA fragments were established and are shown in Fig. 1. We then determined the approximate position of the $t s x$ genes within the cloned DNA segments by probing various single and multiple restriction digests of plasmids pAN-S1, pAN-K1 and pAN-E1 with the labelled DNA hybridization probe derived from $t s x_{\text {E.c. }}$ (Fig. 1).

To examine whether the heterologous $t s x$ genes were expressed in E. coli, plasmids pAN-S1 (tsx $\left.x_{\text {S.t. }}\right)$, pAN-K1 
(a)

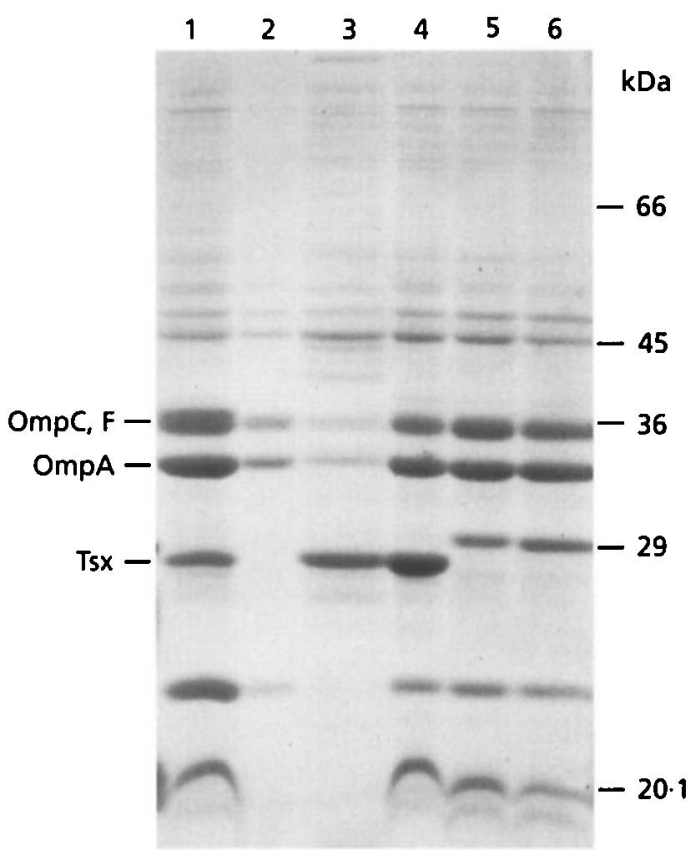

(b)

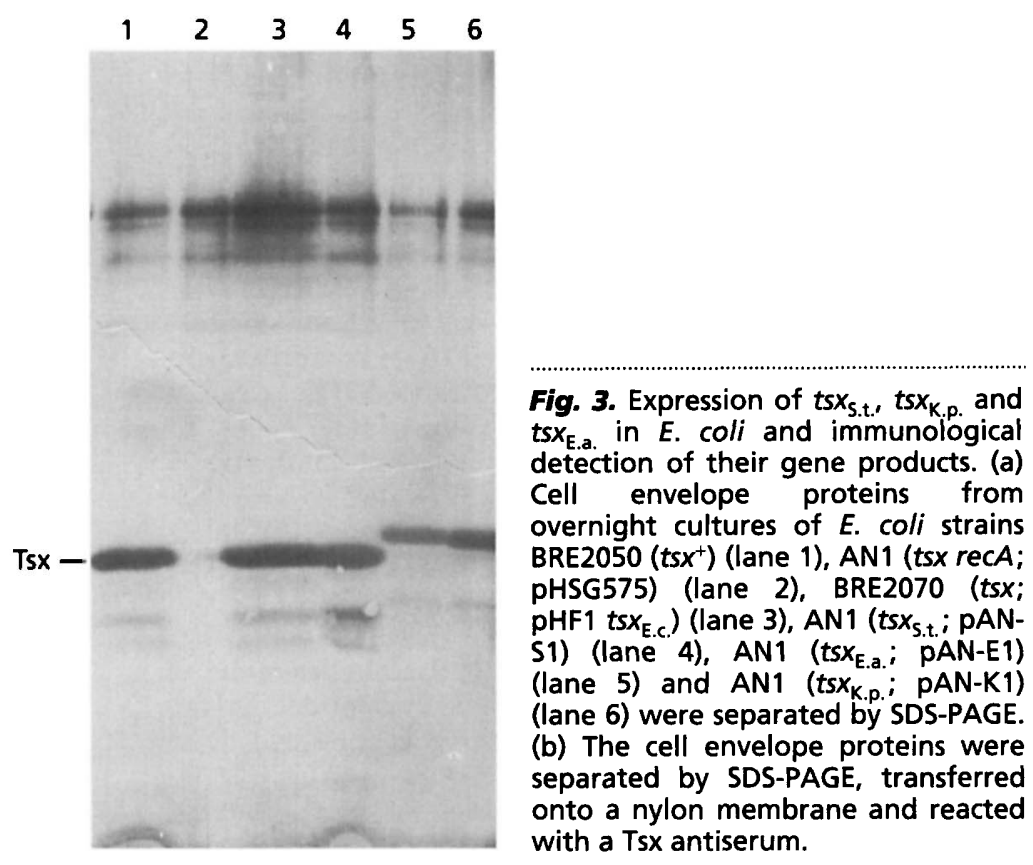

Table 2. Characteristics of Tsx $\mathrm{E.c.}$ Tsx $_{\text {s.t. }}$ and Tsx $\mathrm{K}_{\mathrm{K} . \mathrm{p} .}$

Results shown were confirmed by a second set of experiments.

\begin{tabular}{|c|c|c|c|c|c|c|c|c|c|c|c|}
\hline \multirow{2}{*}{$\begin{array}{l}\text { Plasmid/ } \\
\text { strain* }^{*}\end{array}$} & \multicolumn{8}{|c|}{ Tsx-specific bacteriophages $\dagger$} & \multirow{2}{*}{$\begin{array}{c}\text { Colicin K } \\
\text { (titre) } \ddagger\end{array}$} & \multirow[t]{2}{*}{ Albicidin $\$$} & \multirow{2}{*}{$\begin{array}{c}\text { Nucleoside } \\
\text { uptake } \|\end{array}$} \\
\hline & T6 & T6h3.1 & Ox1 & H1 & H3 & H8 & H9 & K18 & & & \\
\hline pHSG575 & $\mathrm{R}$ & $\mathbf{R}$ & $\mathbf{R}$ & $\mathrm{R}$ & $\mathrm{R}$ & $\mathbf{R}$ & $\mathbf{R}$ & $\mathrm{R}$ & $\mathrm{R}(32)$ & $\mathbf{R}$ & - \\
\hline pHF1 & $\mathrm{S}$ & $\mathrm{S}$ & $\mathrm{S}$ & $\mathrm{S}$ & $\mathrm{S}$ & $\mathrm{S}$ & $S$ & $S$ & S (1024) & $\mathrm{S}$ & + \\
\hline pAN-S1 & $\mathbf{R}$ & $\mathbf{R}$ & $\mathbf{R}$ & $\mathbf{R}$ & $\mathrm{R}$ & $\mathbf{R}$ & $\mathbf{R}$ & $\mathbf{R}$ & S (1024) & $S$ & + \\
\hline pAN-E1 & $\mathrm{S}$ & $\mathrm{S}$ & $S$ & $\mathrm{~S}$ & $10^{-3}$ & $10^{-4}$ & $S$ & $S$ & $S(1024)$ & $\mathrm{S}$ & + \\
\hline pAN-K1 & $\mathrm{S}$ & $\mathrm{S}$ & $S$ & $S$ & $\mathrm{~S}$ & $\mathrm{~S}$ & $S$ & $S$ & $S(1024)$ & $S$ & + \\
\hline BRE2050 $\left(t s x^{+}\right)$ & $\mathrm{S}$ & $S$ & $S$ & $\mathrm{~S}$ & $S$ & $S$ & $S$ & $S$ & $S(1024)$ & $S$ & + \\
\hline
\end{tabular}

* The E. coli strains AN1 (tsx recA) and HF1 (tsx $\left.m e t^{+} i l v^{+} v a l^{\mathrm{R}}\right)$ were used as the host for the vector pHSG575 and the plasmids carrying the various $t s x$ genes. A chromosomal copy of the $t s x^{+}$gene is constitutively expressed in strain BRE2050.

$\dagger$ The sensitivity $(S)$ or resistance $(R)$ of bacterial cells against the bacteriophages was determined by plating serial dilutions of high-titred phage lysates onto bacterial cell lawns in LB soft agar. Phages H1, H3 and H8 formed turbid plaques when plated on lawns of strain AN1 (pAN-E1) synthesizing $\mathrm{Tsx}_{\mathrm{E} . \mathrm{a} .}$.

$¥$ The colicin $\mathrm{K}$ titre is given as the reciprocal of the dilution that still gave complete lysis of the bacterial cells.

$\$$ The susceptibility of bacterial strains to the antibiotic albicidin was determined by placing $50 \mu$ l aliquots of two-fold dilutions into wells $(0.5 \mathrm{~cm})$ cut into LB agar plates overlaid with soft agar containing the bacteria.

$\|$ The initial uptake of $8-\left[{ }^{14} \mathrm{C}\right]$ deoxyadenosine was measured in cells grown in minimal medium with $0 \cdot 2 \%$ glycerol as carbon source at a final substrate concentration of $0.55 \mu \mathrm{M}$.

$\left(t s x_{\mathrm{K} . \mathrm{p} .}\right)$ and pAN-E1 (ts $\left.x_{\mathrm{E.a}}\right)$ were separately transformed into strain AN1 (tsx recA) and the OMP profile of the transformants was analysed by SDS-PAGE. Each of these transformants produced a new OMP that reacted with the Tsx antiserum (Fig. 3). Thus the cloned genomic DNA segments from $S$. typhimurium, $K$. pneumoniae and Ent. aerogenes do encode proteins

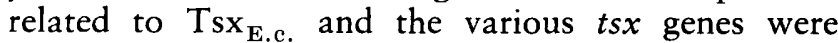
efficiently expressed in an $E$. coli host. The Tsx proteins were routed into the outer membrane, demonstrating that the topogenic signals required for their proper insertion into this cell compartment are evolutionarily conserved. Due to the low copy number of the $t s x^{+}$ plasmids, the various Tsx proteins were not strongly overproduced in comparison to the $E$. coli strain BRE2050 (Fig. 3), which expresses a chromosomal copy of $t s x_{\text {E.c. }}$ constitutively due to mutations in the $c y t R$ and deoR repressor genes (Bremer et al., 1988). 


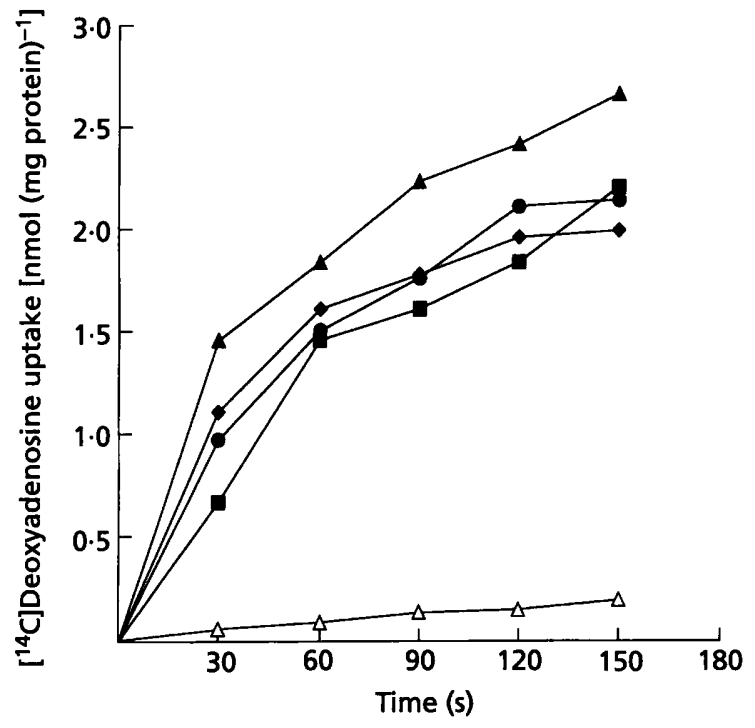

Fig. 4. Nucleoside uptake mediated by $T s x_{5 . t .}, T s x_{K . p .}$ and $T s x_{E . a .}$. The initial transport of $\left[{ }^{14} \mathrm{C}\right]$ deoxyadenosine at a final substrate concentration of $0.55 \mu \mathrm{M}$ was measured in $E$. coli HF1 (tsx) carrying the vector pHSG575 $(\triangle)$, plasmid pHF1 $\left(t_{5 x_{E, C}}\right)(\Delta)$,

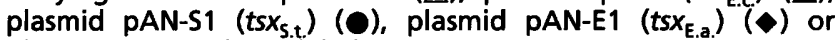
plasmid pAN-K1 (tsx $\left.x_{\text {K.p. }}\right)(\boldsymbol{D})$.

\section{Functional characterization of the $\operatorname{Tsx}_{\text {s.t. }}, \mathbf{T s x}_{\mathrm{K.p.}}$ and Tsx E.a.}

Derivatives of strain AN1 (tsx recA) and HF1 (tsx $m e t^{+}$ $\left.i l v^{+} v a l^{\mathrm{R}}\right)$ carrying the cloned $t s x_{\mathrm{S} . t .}, t s x_{\mathbf{K} . \mathrm{p} .}$ and $t s x_{\mathrm{E} . \mathrm{a}}$. genes were used to compare the functional properties of the heterologous $\mathrm{Tsx}$ proteins with those of $\mathrm{Tsx} \mathrm{x}_{\mathrm{E} . \mathrm{c} \text {. }}$ (Table 2). The nucleoside-specific channel activity of the Tsx protein (Benz et al., 1988; Maier et al., 1988) can be monitored in vivo by measuring deoxynucleoside uptake at submicromolar substrate concentrations (Fsihi et al., 1993; Hantke, 1976; Krieger-Brauer \& Braun, 1980). We measured the initial transport of $\left[{ }^{14} \mathrm{C}\right]$ deoxyadenosine in strains expressing the $t s x_{\mathrm{S} . t .}, t s x_{\mathrm{K} . \mathrm{p} .}$ and $t s x_{\text {E.a. }}$ genes at a final substrate concentration of $0.55 \mu \mathrm{M}$. Derivatives of HF1 carrying $t s x_{\text {E.c. }}$ on plasmid pHF1 or the vector pHSG575 showed the expected strong dependence on the Tsx protein for $\left[{ }^{14} \mathrm{C}\right]$ deoxyadenosine uptake at such a low substrate concentration (Fig. 4). Each of the heterologous Tsx proteins facilitated the efficient uptake of the deoxynucleoside and there was no strong difference in the initial rate of $\left[{ }^{14} \mathrm{C}\right]$ deoxyadenosine transport in comparison to strains synthesizing $T s x_{\mathrm{E} . c .}$. Likewise, each of the $E$. coli strains expressing one of the heterologous $t s x$ genes was fully sensitive to the antibiotic albicidin (Table 2) which depends on the Tsx channel for its permeation across the outer membrane (Birch et al., 1990; Fsihi et al., 1993). Hence, the $T \mathrm{Tx}_{\mathrm{S} \text {.t. }}$, $T \mathrm{Tx}_{\mathrm{K} . \mathrm{p.}}$ and $T \mathrm{sx}_{\mathrm{E.a.}}$ each function as a substrate-specific channel.

The heterologous Tsx proteins could also operate with the same efficiency as $T_{s x_{E} \text {.c. }}$ as receptors for colicin $\mathrm{K}$ (Table 2); however, they differed in their ability to serve as receptor for $T s x$-specific bacteriophages. $T s x_{K . p}$. conferred full sensitivity to a panel of eight Tsx-specific phages. Tsx $\mathrm{E}_{\mathrm{E} . \mathrm{a}}$. showed a partial defect in its bacteriophage receptor function: it could serve as a receptor protein for phages $\mathrm{T} 6, \mathrm{~T} 6 \mathrm{~h} 3.1, \mathrm{Ox} 1, \mathrm{~K} 9, \mathrm{~K} 18$ and $\mathrm{H} 1$, but the plating efficiency of phages $\mathrm{H} 3$ and $\mathrm{H} 8$ was markedly reduced (Table 2 ). In contrast, the strain synthesizing $\mathrm{Tsx}_{\mathrm{S} . t .}$. was fully resistant to these bacteriophages (Table 2) and cultures of AN1 (pAN-S1) were also unable to neutralize any of the Tsx-specific phages (data not shown), indicating that $\mathrm{Tsx}_{\mathrm{S} \text {.t. }}$ was not recognized as a receptor by these Tsx-specific bacteriophages. This is a specific effect associated with $T s x_{\text {.t. }}$. since strain AN1 (pAN-S1) was fully sensitive to the OmpA- and LamB-specific phages TuII* and $\lambda v i r$ (data not shown). Consequently, synthesis of $\mathrm{Tsx}_{\mathrm{S} . t .}$ in $E$. coli does not result in a general pattern of phage resistance. The results summarized in Table 2 demonstrate that $T s x_{\text {S.t. }}, T s x_{K . p .}$ and $T s x_{\text {E.a. }}$ can fully functionally replace $T s x_{\text {E.c. }}$ with respect to its nucleoside-specific channel activity, its role in albicidin uptake and colicin $\mathrm{K}$ receptor function. This suggests that the overall topological organization of the Tsx proteins within the outer membrane is likely to be well conserved. However, the differences in the phage receptor function among the various $T s x$ polypeptides indicate that $T_{s x_{\text {S.t. }} \text { and }}$ $\mathrm{Tsx}_{\text {E.a. }}$ underwent evolutionary changes in those cellsurface-exposed segments that constitute the phage receptor areas.

\section{Nucleotide sequence of $t s x_{s . t,} t s x_{K, p .}$ and $t s x_{E . a .}$}

We determined the nucleotide sequence of $t s x_{\text {S.t. }}, t s x_{\mathrm{K} . p .}$. and $t s x_{\text {E.a. }}$ and their flanking regions from restriction fragments cloned into derivatives of phage M13. Each of the $t s x$ coding regions begins with an ATG start codon that is preceded by a putative ribosome-binding site complementary to the $3^{\prime}$ end of the 16S RNA, and this region has a typical spacing of $7 \mathrm{bp}$ to the start codon (Fig. 5). Like their E. coli counterpart, the ts $x_{\mathrm{K} . p .}$ and $t s x_{\text {E.a. }}$ reading frames comprise 294 codons. $t s x_{\text {S.t. }}$ encodes a protein of only 287 residues: there is an insertion of an additional codon and a deletion of 8 codons from the $t s x_{\text {S.t. }}$ reading frame. The DNA sequences of the $t s x$ coding regions exhibit a high degree of sequence homology, with $69 \%$ of the base pairs being identical in $t s x_{\text {E.c. }}, t s x_{\text {S.t. }}, t s x_{\text {K.p. }}$ and $t s x_{\mathrm{E.a}}$. Many of the observed nucleotide changes result in the switch to synonymous codons and are thus of no consequence for the properties of the various Tsx proteins. However, four short DNA segments had a high proportion of base pair changes that result in the substitution of many amino acid residues in the corresponding segments of the Tsx proteins (Fig. 6).

Expression of $t s x_{\text {E.c. }}$ is co-regulated with the systems for nucleoside uptake and metabolism. Mapping of the transcription initiation sites for the ts $x$ mRNAs and genetic analysis of the pattern of $t s x$ regulation have shown that $t s x$ transcription initiates from two differently regulated promoters. The upstream promoter $(t s x-p 1)$ is negatively controlled by the DeoR repressor and due to its low level of activity contributes very little 


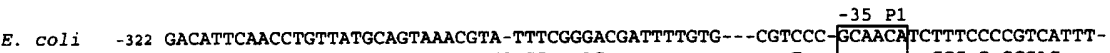

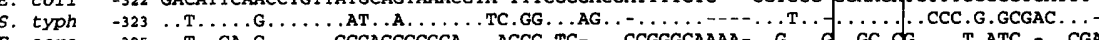

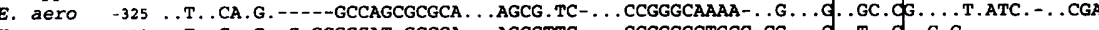

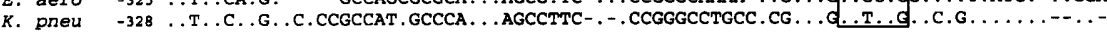

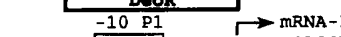

E. coli

S. typh

E. aero

K. preu

-247 TGTTACTCTIGCTTACA---TCACCTGGATTGATAGTAAAAGTTTGCAACAAGG-GCGAAAGTCAGTACAATCCCCG-CCCG

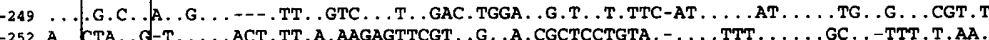

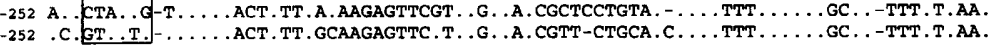

E. coli

S. typh

E. aero

K. pneu
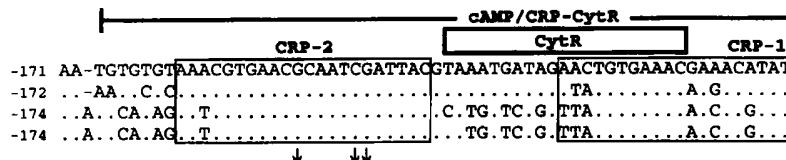

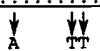

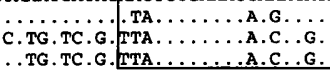

A.C.G.

174 . . . . CA.AG.

\section{(1)}

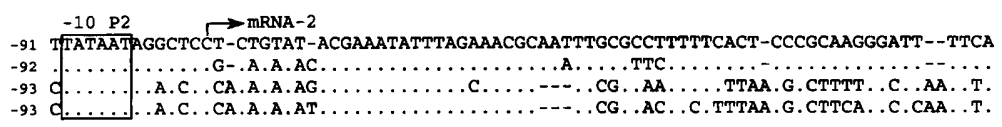

E. $\operatorname{col} 1$

S. typh

E. aero

K. pneu

$-93$ A.C. CA.A.A.AT.

\begin{tabular}{|c|c|c|c|c|}
\hline & & rbs & & $\mathrm{Me}$ \\
\hline coli & -1 & A $\overline{A C A G T G}$ & GATACAT & AT \\
\hline & -15 & $\ldots$ & $\ldots \ldots$ & .. \\
\hline & -15 & . A. & CA.C & .. \\
\hline & -15 & & . TAC. & . \\
\hline
\end{tabular}

Fig. 5. Nucleotide sequence of the tsx regulatory regions from $E$. coli, $S$. typhimurium, $K$. pneumoniae and Ent. aerogenes. The -10 and -35 sequences of the tsx-p1 and tsx-p2 promoters are boxed and the transcription initiation sites for both tsx $x_{E . c .}$ mRNAs are indicated by arrows above the nucleotide sequence (Bremer et al., 1990). Potential ribosome binding sites (rbs) for the tsx genes are boxed. The putative DeoR-binding site overlapping the tsx-p1 -10 region and the position of the binding sites for CAMP/CRP, CytR and CAMP/CRP plus CytR, which were identified by high resolution footprinting analysis in $t s x_{E . c .}$ are indicated. The nucleotide changes of mutations affecting the formation of the CAMP/CRP and CytR nucleoprotein complex at tsx-p2 (Gerlach et al., 1991) are marked by downward-directed arrows.

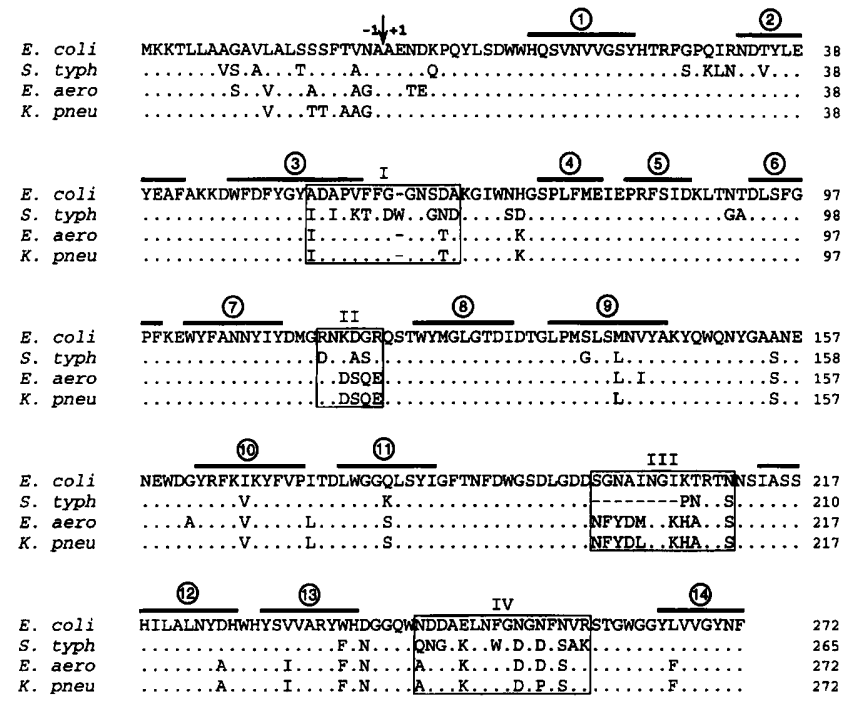

Fig. 6. Alignment of the deduced amino acid sequences of

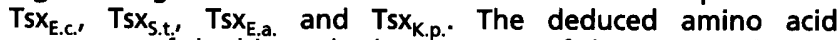
sequences of the biosynthetic precursors of the Tsx proteins are aligned. The putative cleavage site for the signal sequence peptidase is indicated by a downward-directed arrow. The positions of the predicted membrane-spanning segments of the Tsx proteins are indicated by bars. Amino acid residues identical in each of the four aligned proteins are marked with dots and missing amino acids are indicated by hyphens. Four hypervariable regions in the Tsx proteins are boxed.

to total Tsx production (Bremer et al., 1988, 1990; Krieger-Brauer \& Braun, 1980). The major promoter $(t s x-p 2)$ is activated by the cAMP/CRP complex and is negatively regulated by the CytR protein (Bremer et al., 1990; Gerlach et al., 1991). The nucleotide sequences of the regulatory regions of $t s x$ genes from $t s x_{\mathrm{S.t.}}, t s x_{\mathrm{K} . \mathrm{p}}$ and $t s x_{\text {E.a. }}$ are shown in Fig. 5, where they are compared with the corresponding region of $t s x_{E . c .}$. The overall sequence homology in this DNA segment is much lower than that of the $t s x$ coding regions but several highly conserved regions are apparent. These conserved DNA segments are centred around the CytR- and cAMP/CRP-controlled $t s x-p 2$ promoter, where two cAMP/CRP binding sites and a CytR binding region have been identified by high-resolution footprinting analysis (Gerlach et al., 1991). The CytR repressor and the cAMP/CRP activator bind co-operatively to the $t s x$ $p 2$ area in E. coli and form an extended nucleoprotein complex that reaches close to the -10 region of the promoter (Gerlach et al., 1991). The conservation of these sequences in the $t s x$ genes thus likely reflects their common genetic control by the CytR and cAMP/CRP regulatory proteins (Valentin-Hansen et al., 1996). In contrast, the DNA sequences around the rather weak, DeoR-controlled E. coli ts $x$ - $p 1$ promoter (Bremer et al., 1990) are not particularly well conserved (Fig. 5). It is therefore questionable whether such a promoter also operates in $t s x_{\text {S.t. }}, t s x_{\mathrm{K} . p .}$ and $t s x_{\mathrm{E} . \mathrm{a} .}$.

The nucleotide sequence distal to the $t s x$ stop codons varies considerably among the four determined DNA regions. A copy of a REP element, which is a highly repetitive extragenic palindromic sequence dispersed around the bacterial chromosome (Bachellier et al., 1996), is present distal to the $3^{\prime}$ end of the $t s x_{\text {E.c. }}$ coding region (Bremer et al., 1990). Such REP sequences can also be found in the $3^{\prime}$ segments of $t s x_{\mathrm{S} . t .}, t s x_{\mathrm{K} . \mathrm{p} .}$ and $t s x_{\text {E.a. }}$ (data not shown). An extra piece of DNA $\left(453 \mathrm{bp}\right.$ ) downstream of the $t s x_{\mathrm{S} . t}$. coding region is absent from the corresponding regions of the other $t s x$ genes. Within this DNA segment, a short ORF (orf $X$ ) 
can be found (Fig. 1) that could encode a 132 amino acid residue protein with a calculated $M_{\mathrm{r}}$ of 14508 . The deduced OrfX protein has no homology to any other protein currently represented in the databases. We detected in the S. typhimurium DNA sequence downstream of orf $X$ another ORF, orf6 (Fig. 1), which could encode a 109 amino acid residue protein $\left(M_{r} 12623\right)$. The orf6-encoded protein exhibits high sequence identity $(95 \%)$ to a previously described protein (Orf6) with unknown function encoded by the tsx-orf6-secF region of the E. coli chromosome (Lucht et al., 1992).

\section{Features of the Tsx proteins}

Tsx $\mathbf{E}_{\mathbf{E}_{\text {.c. }} \text {. }}$ is initially synthesized with an amino-terminal signal sequence that is required for its translocation across the cytoplasmic membrane (Bremer et al., 1990). The amino-terminal 22 amino acid residues of each Tsx protein exhibited the characteristic features of a prokaryotic signal sequence (Michaelis \& Beckwith, 1982). Many amino acid substitutions, in particular in the hydrophobic core of the signal sequence, are present in this region (Fig. 6), but due to the conservative nature of these alterations, none of these changes are expected to impair the function of the Tsx signal sequence. The predicted mature proteins $\mathrm{Tsx}_{\mathrm{S} . t .}$ ( 265 residues), $\mathrm{Tsx}_{\mathrm{K} . p}$. (272 residues) and $T s x_{\text {E.a. }}$ ( 272 residues) have a calculated $M_{r}$ of 30567,31412 and 31477 , respectively. Comparison of the amino acid sequences revealed a high degree of sequence identity between the proteins, strongly suggesting that the overall tertiary structure of these polypeptides is very similar in all four species. A pairwise comparison of the mature $T \mathbf{s x}_{\mathrm{S.t.}}, T s \mathrm{x}_{\mathrm{K} . \mathbf{p .} \text {. }}$ and $\mathrm{Tsx}_{\mathrm{E} \text {.a. }}$ sequences with that of $\mathrm{Tsx}_{\mathrm{E} \text {.c. }}$ showed sequence identities of $83.7 \%, 88.6 \%$ and $87 \cdot 1 \%$, respectively. Approximately $78 \%$ of the amino acid residues are identical among all four Tsx proteins, but there are four regions which show a considerable degree of sequence variability (Fig. 6). Such an alternation between highly conserved and hypervariable regions has also been found in several other OMPs (e.g., OmpA, PhoE, LamB) and these highly variable segments are generally regarded to represent cell-surface-exposed domains (Braun \& Cole, 1984; van der Ley et al., 1987; Werts et al., 1992). The insertion of a single amino acid residue into and the deletion of 8 residues from Tsx $_{\text {S.t. }}$, have occurred in such hypervariable regions (Fig. 6). Approximately $40 \%$ of the differences between the Tsx proteins involve conservative amino acid substitutions and many of these alterations have occurred in well-conserved portions of Tsx (Fig. 6). In contrast, most of the non-conservative changes have taken place in the hypervariable segments (Fig. 6). Tsx $\mathrm{E}_{\text {E.c. }}, \mathrm{Tsx}_{\mathrm{s} . \mathrm{t} .}$ and $T s \mathrm{x}_{\mathrm{E.a}}$. each contain 52 charged residues; 32 are acidic and 20 are basic. There are 31 acidic and 20 basic amino acid residues present in $\mathrm{Tsx}_{\mathrm{K} . \mathrm{p} \text {. }}$ Thus, each of the Tsx proteins has a net negative charge of $-12(-11)$ residues, a value similar to that observed for the channel-forming proteins $\mathrm{OmpC}$ $(-14)$, OmpF (-11), PhoE (-9) and LamB (-19) (Bremer et al., 1990). Like most porins (Gerbl-Rieger et al., 1991), none of the Tsx proteins contains a cysteine residue. A database search for proteins homologous to Tsx did not reveal any significant sequence identity to any other known general porins or substrate-specific channels. The Tsx proteins are, however, distantly related (approximately $29 \%$ identity) to OmpK, a $26 \mathrm{kDa}$ OMP from Vibrio parahaemolyticus with unknown function that serves as a receptor for the broadhost-range vibriophage KVP40 (Inoue et al., 1995).

\section{Site-directed mutagenesis of $t s x_{\mathrm{E} . \mathrm{C} .}$ and $t s \mathrm{x}_{\mathrm{s.t} .}$}

An important difference in the functions of the various Tsx proteins was the lack of phage receptor activity of $\mathrm{Tsx}_{\mathrm{S} . \mathrm{t}}$. produced by an E. coli host strain (Table 2). A deletion of 8 amino acids is present in one of the hypervariable, and thus most likely cell-surface-exposed domains of $\mathrm{Tsx}_{\text {s.t. }}$ (Fig. 6). We wondered whether this prominent change was the cause for the resistance against Tsx-specific bacteriophages. To address this question, we used site-directed mutagenesis to introduce a $24 \mathrm{bp}$ deletion into the corresponding portion of $t s x_{\mathrm{E} . c .}$, resulting in the removal of residues Ser-199 to Ile-206 and the construction of the $t s x-515$ mutation. Conversely, we introduced a 24 bp DNA segment into $t s x_{\mathrm{S} . t .}$ which caused the insertion of 8 amino acids between residues Asp-199 and Pro-200 of Tsx $\mathrm{s}_{\text {.t. }}$, yielding the $t s x-520$ mutation. The amino acid sequence of the inserted peptide (Ser-Gly-Asn-Ala-Ile-Asn-GlyIle) was identical to that removed by the $t s x-515$ deletion

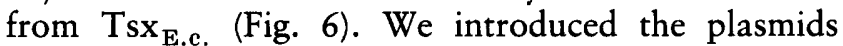
carrying the tsx-515 (pTX5- $\Delta 1$ ) and ts $x-520$ (pAN$\mathrm{S} 1:: 1)$ mutations into strain $\mathrm{AN} 1$ and analysed the OMP profile of the resulting strains by SDS-PAGE. The Tsx-515 and Tsx-520 proteins were produced in amounts similar to that of their wild-type counterparts (data not shown) and are thus stable mutant derivatives of Tsx.

The removal of residues Ser-199 to Ile-206 from Tsx $\mathbf{x}_{\text {E.c. }}$ (Tsx-515) resulted in complete resistance against Tsxspecific phages (Table 3), suggesting that this segment of the Tsx polypeptide is an important determinant for phage receptor function. This finding also implies that the region between Ser-199 and Ile-206 is exposed at the cell surface. In contrast, the insertion of 8 amino acid residues between Asp-199 and Pro-200 into Tsx S.t. $_{\text {. }}$ (Tsx520) did not endow the mutant protein with full phage receptor function. Synthesis of the Tsx-520 protein permitted the efficient plating of phage T6h3.1, an extended host-range mutant of T6 (Maier et al., 1990; Schneider et al., 1993) and also allowed the propagation of phage $\mathrm{T} 6$ to some degree, but the Tsx-520 protein did not function as receptor for the Tsx-specific phages $\mathrm{Ox} 1, \mathrm{H} 1, \mathrm{H} 3, \mathrm{H} 8, \mathrm{~K} 9$ and $\mathrm{K} 18$ (Table 3). Consequently, the deletion present in $t s x_{\mathrm{S} . \mathrm{t}}$ is clearly not the sole cause for the lack of phage receptor activity of $\mathrm{Tsx}_{\mathrm{S} . t .}$. We also characterized the properties of strains AN1 (pTX5- $\Delta 1$ ) and AN1 (pAN-S1::1) with respect to their sensitivity against colicin K. Strains HF1 (pTX5- $\Delta 1$ ) and HF1 (pAN-S1::1) were examined for their susceptibility to the antibiotic albicidin and their $\left[{ }^{14} \mathrm{C}\right]$ deoxyadenosine 
Table 3. Properties of the mutant E. coli Tsx-515 and the S. typhimurium Tsx-520 proteins

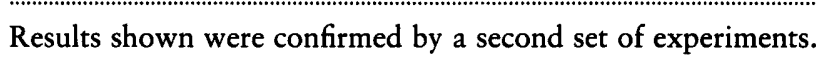

\begin{tabular}{|c|c|c|c|c|c|c|c|c|c|c|c|}
\hline \multirow[t]{2}{*}{ Plasmid* } & \multicolumn{8}{|c|}{ Tsx-specific bacteriophages } & \multirow{2}{*}{$\begin{array}{c}\text { Colicin K } \\
\text { (titre) }\end{array}$} & \multirow[t]{2}{*}{ Albicidin } & \multirow{2}{*}{$\begin{array}{l}\text { Nucleoside } \\
\text { uptake }\end{array}$} \\
\hline & T6 & T6h3.1 & Ox1 & H1 & $\mathbf{H 3}$ & H8 & H9 & K18 & & & \\
\hline pBR322 & $\mathbf{R}$ & $\mathbf{R}$ & $\mathrm{R}$ & $\mathbf{R}$ & $\mathbf{R}$ & $\mathrm{R}$ & $\mathrm{R}$ & $\mathbf{R}$ & $\mathbf{R}(32)$ & $\mathrm{R}$ & - \\
\hline pTX5 & $\mathrm{S}$ & $\mathrm{S}$ & $\mathrm{S}$ & $\mathrm{S}$ & $\mathrm{S}$ & $\mathrm{S}$ & $\mathrm{S}$ & $\mathrm{S}$ & $S(1024)$ & $S$ & + \\
\hline pTX5- $\Delta 1$ & $\mathrm{R}$ & $\mathbf{R}$ & $\mathbf{R}$ & $\mathbf{R}$ & $\mathbf{R}$ & $\mathbf{R}$ & $\mathbf{R}$ & $\mathrm{R}$ & S (1024) & $\mathrm{S}$ & + \\
\hline pHSG575 & $\mathrm{R}$ & $\mathbf{R}$ & $\mathbf{R}$ & $\mathbf{R}$ & $\mathrm{R}$ & $\mathbf{R}$ & $\mathrm{R}$ & $\mathbf{R}$ & $\mathbf{R}(32)$ & $\mathbf{R}$ & - \\
\hline pHF1 & $\mathrm{S}$ & $\mathrm{S}$ & $\mathrm{S}$ & $\mathrm{S}$ & $\mathrm{S}$ & $\mathrm{S}$ & $\mathrm{S}$ & $\mathrm{S}$ & S (1024) & $S$ & + \\
\hline pAN-S1 & $\mathrm{R}$ & $\mathrm{R}$ & $\mathrm{R}$ & $\mathbf{R}$ & $\mathrm{R}$ & $\mathrm{R}$ & $\mathrm{R}$ & $\mathbf{R}$ & $S(1024)$ & $S$ & + \\
\hline pAN-S1::1 & $10^{-6}$ & $10^{-1}$ & $\mathbf{R}$ & $\mathrm{R}$ & $\mathrm{R}$ & $\mathrm{R}$ & $\mathrm{R}$ & $\mathrm{R}$ & $S(1024)$ & $S$ & + \\
\hline
\end{tabular}

* The E. coli strains AN1 (tsx recA) and HF1 (tsx met $\left.t^{+} i v^{+} v a l^{\mathrm{R}}\right)$ were used as the host for the vectors pBR322 and pHSG575 and for the plasmids harbouring the various $t s x$ genes. Plasmids pTX5 $\left(t s x^{+}\right)$and pTX5- $\Delta 1(t s x-515)$ are derivatives of pBR322 and carry $t s x_{\mathrm{E} . c .}$. Plasmids pHF1, pAN-S1 and pAN-S1:: 1 are based on the pHSG575 replicon and carry $t s x_{\text {E.c. }}$ (pHF1) and $t s x_{\text {S.t. }}$ (pAN-S1) or its $t s x-520$ mutant derivative, pAN-S1::1.

uptake activity was measured. The Tsx-515 and Tsx520 proteins were fully proficient in $\left[{ }^{14} \mathrm{C}\right]$ deoxyadenosine transport and conferred full sensitivity to colicin $\mathrm{K}$ and albicidin (Table 3 ), demonstrating that the deletion present in Tsx-515 and the insertion in Tsx-520 did not cause an indiscriminate loss of all Tsx functions.

\section{Membrane topology of the Tsx protein}

The recent elucidation of the atomic structure and outer-membrane topology of porins from Rhodobacter capsulatus, Rhodopseudomonas blastica and the $\mathrm{OmpF}$ and PhoE porins from E. coli (Cowan et al., 1992; Kreusch \& Schulz, 1994; Weiss et al., 1991) has greatly advanced our understanding of the structure-function relationship of these types of pore-forming proteins. A common picture of the architecture of general diffusion pores has emerged from these crystallographic studies. The native form of the porins is a trimer with each subunit containing a pore. The channel-forming motif is an anti-parallel $\beta$-barrel with very short connecting loops of transmembrane $\beta$-strands on the periplasmic side of the membrane and extended cell-surface-exposed loops of variable length. The membrane-spanning $\beta$ strands surrounding the aqueous pore have an amphipathic character; they face the lipid phase with their hydrophobic side and line the channel with their hydrophilic portion. These $\beta$-strands are tilted with respect to the plane of the membrane and their length varies in the $R b$. capsulatus porin from 6 to 17 amino acid residues (Weiss et al., 1991). The same basic building principles also apply to substrate-specific diffusion channels such as the maltoporin LamB from $E$. coli (Schirmer et al., 1995), despite the absence of sequence homology between LamB and the general porins.

By taking into account the information derived from the $\mathrm{X}$-ray structure analysis of porins, the analysis of hydrophobicity and amphipathicity of $\beta$-strands and multiple sequence alignments, Pattus and co-workers
(Jeanteur et al., 1991, 1994) have developed a set of tools that can be used for the prediction of transmembrane topology of pore-forming proteins with unresolved Xray structure (Huang et al., 1995). We have applied these rules to the Tsx sequences to develop a two-dimensional model for the topological organization of this protein within the E. coli outer membrane (Fig. 7). In this model, the 272-residue Tsx protein is depicted as a $\beta$-barrel with 14 membrane-spanning segments and each of the proposed transmembrane $\beta$-strands has an amphipathic character. The OmpF, PhoE and general porins from $E$. coli, $R b$. capsulatus and $R p$. blastica contain 16 such $\beta$ strands (Cowan et al., 1992; Kreusch \& Schulz, 1994; Weiss et al., 1991) and 18 membrane-spanning segments are present in the maltodextrin-specific LamB protein (Schirmer et al., 1995). The lower number of the predicted membrane-spanning strands in Tsx might indicate that the interior of the Tsx channel is much more restrictive than those of the general porins and LamB. Consistent with this idea is the very low singlechannel conductance of $10 \mathrm{pS}$ found when the purified Tsx protein was reconstituted into black lipid membranes (Benz et al., 1988; Maier et al., 1988), a value considerably smaller than that measured for the general diffusion pores OmpF (1500 pS) and OmpC (1900 pS), and for the substrate-specific LamB channel (155 pS) under the same reconstitution conditions (Benz, 1994). The lengths of the putative $\beta$-strands in Tsx vary from 6 to 13 residues, with the majority of the membranespanning segments having a size of 9-10 residues, a value similar to that found in LamB and the E. coli, $R b$. capsulatus and Rp. blastica porins.

The sequences of each of the proposed 14 membranespanning $\beta$-strands in Tsx (Fig. 7) are highly conserved and contain, with the exception of two positions in Tsx $_{\text {s.t. }}$, only conservative substitutions (Fig. 6); these changes thus do not alter the amphipathic character of the membrane-spanning segments. This high degree of sequence conservation likely reflects structural con- 


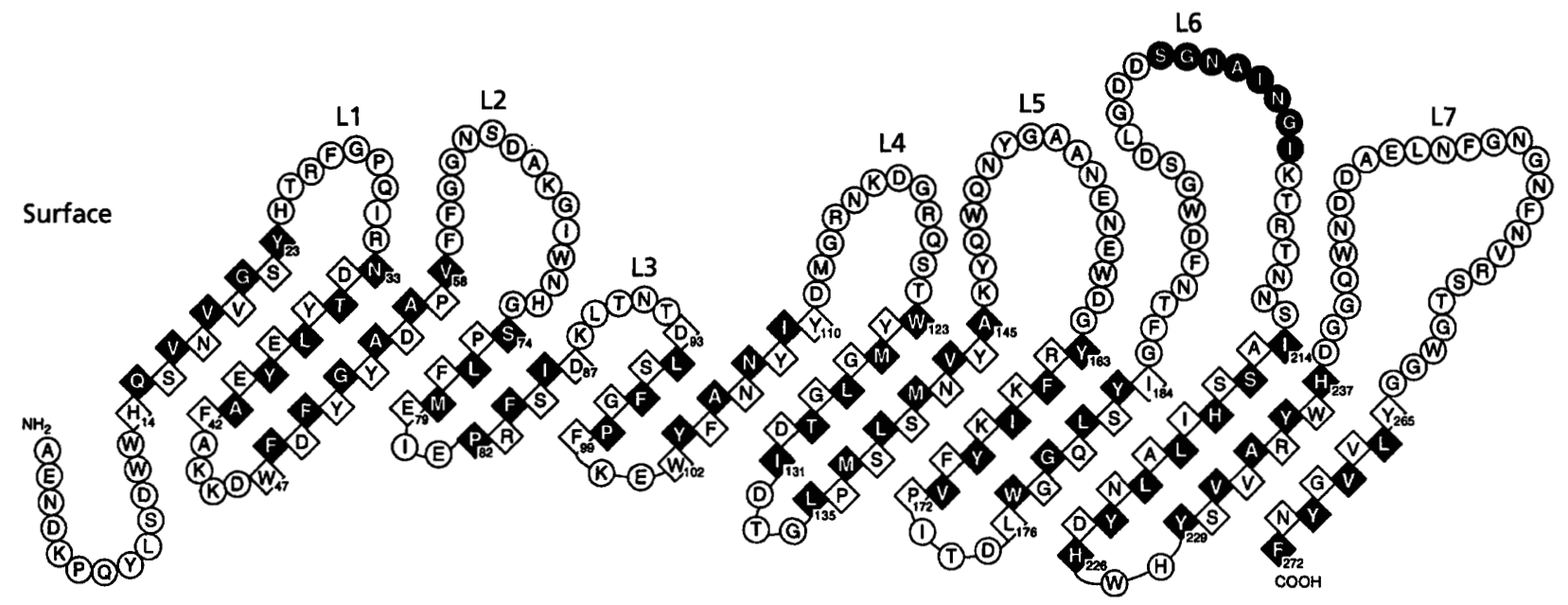

Periplasm

Fig. 7. Proposed membrane topology of $\mathrm{Tsx}_{\mathrm{E.C}}$. Residues that are part of the predicted transmembrane segments are boxed. The hydrophobic sides of each of the 14 putative $\beta$-strands are indicated as black boxes. The 8 amino acid residues in loop L6 between Ser-199 and Ile-206 in Tsx $\mathrm{E}_{\mathrm{E} . \mathrm{C}}$ which were removed by site-directed mutagenesis are indicated in black.

straints imposed on the properties of the $\beta$-strands by the overall porin architecture. The aromatic residues in the transmembrane segments of Tsx tend to cluster near the ends of the $\beta$-strands where they could contribute to the formation of two hydrophobic girdles that are thought to stabilize the $\beta$-barrel structure within the membrane (Cowan et al., 1992; Kreusch \& Schulz, 1994; Schirmer et al., 1995).

The amphipathic nature of the last $\beta$-strand is highly conserved in many OMPs and plays an important role for their proper membrane insertion. A phenylalanine facing the periplasmic side of the membrane is frequently found at the very carboxy-terminal end of these polypeptides (Struyvé et al., 1991) and such a residue is also present at this position in each of the four Tsx proteins (Fig. 6). Both the carboxy- and amino-terminal ends of Tsx are envisioned in our model to face the periplasm (Fig. 7), consistent with the known location of these termini in the solved porin and LamB structures (Cowan et al., 1992; Kreusch \& Schulz, 1994; Schirmer et al., 1995; Weiss et al., 1991). Each of the postulated periplasmic turns in the Tsx polypeptide comprises just a few residues (2-4 amino acids), which should give the lower rim of the Tsx $\beta$-barrel a rather regular shape similar to that found in the known porin structures. There is no sequence variation among the Tsx proteins (Fig. 6) in any of the proposed periplasmic turns. In contrast, the presumed cell-surface-exposed domains vary considerably in length, ranging from 5 to 29 residues (Fig. 7), and 4 of the proposed 7 external loops comprise hypervariable regions of the Tsx polypeptide chain (Fig. 6).

\section{Implications for the functional organization of Tsx}

There is good evidence from the analysis of several enterobacterial OMPs, that hypervariable regions rep- resent cell-surface-exposed domains and frequently constitute binding sites for colicins, bacteriophages and antibodies (Braun \& Cole, 1984; van der Ley et al., 1987; Werts et al., 1992). Their sequence variability might thus reflect a strong selective pressure for resistance against a number of lethal agents present in the natural habitats of these micro-organisms. We have previously identified single amino acid substitutions at residues Asn-249 and Asn-254 which specifically abolish the phage receptor function of Tsx, and a deletion of residues from Gly-239 to Asp-244 which simultaneously destroys its phage and colicin $\mathrm{K}$ receptor activity (Maier et al., 1990; Schneider et al., 1993). These residues are all part of the hypervariable loop L7 close to the carboxyterminal end of Tsx. As demonstrated in this report, the removal of 8 amino acid residues (Ser-199 to Ile-206) from the hypervariable L6 area also results in resistance against Tsx-specific phages without impairing the colicin $\mathrm{K}$ receptor activity or substrate-specific channel function of the Tsx protein (Table 3). Thus, there is experimental evidence to support the proposed cell surface location of both loops L6 and L7, but further studies are required to confirm the presumed location of the other loops (Fig. 7).

A genetic approach to detect mutant Tsx proteins with altered channel characteristics has identified single amino acid substitutions at residues Phe-27, Gly-28, Gly-239 and Gly-240 that result in resistance to the antibiotic albicidin and impair the nucleoside uptake function of Tsx in vivo (Fsihi et al., 1993). The affected residues are part of the cell-surface loops L1 (Phe-27, Gly-28) and L7 (Gly-239, Gly-240) (Fig. 7) and these changes might thus negatively influence the entry of nucleosides and albicidin into the Tsx channel. In a similar manner many point mutations in $\operatorname{lamB}$ with a negative influence on sugar binding and translocation through the maltodextrin-specific LamB channel affect 
residues on cell-surface loops which form an umbrella covering the entrance to the channel (Hofnung, 1995). Residue Ser-217 in Tsx is part of the hydrophilic face of transmembrane $\beta$-strand number 12 (Fig. 7) and its side chain should thus be exposed to the aqueous channel. The substitution of Ser-217 with an Arg residue causes a severe defect in nucleoside uptake and strong resistance against albicidin (Fsihi et al., 1993). These findings suggest that either Ser-217 might be part of the substratespecific filter within the Tsx channel, or the positive charge and the bulky side chain of the Arg residue introduced by the mutation might obstruct the lumen of the pore. The functional importance of the amino acid residues altered in the albicidin-resistant $E$. coli $t s x$ mutants is emphasized by their conservation in the $T s x_{\text {S.t. }}, T s x_{E . a .}$ and $T s x_{K . p .}$. polypeptides, with the

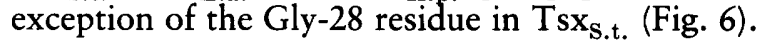

An important feature of both the general porins and the maltodextrin-specific LamB channel is the presence of a long loop on the cell surface side of the membrane that folds back into the channel where it constricts the pore to an eyelet and influences the biophysical properties of the channel (Cowan et al., 1992; Kreusch \& Schulz, 1994; Schirmer et al., 1995; Weiss et al., 1991). This loop links the $\beta$-strands 5 and 6 in the porins and LamB but the corresponding segment in the proposed Tsx model is rather short. It is currently unclear which loop might serve a comparable function for the architecture of the Tsx channel. The model for the topology of Tsx presented here will thus serve as a very useful tool to guide future studies on the structure of the substratespecific Tsx channel and its function as bacteriophage and colicin receptor.

\section{ACKNOWLEDGEMENTS}

We thank M. Dahl, M. Ehrmann, H. Fsihi, K. Hantke, J. Lengeler, P. Reeves and G. Walker for providing bacterial strains, plasmids and bacteriophages. We are grateful to $F$. Pattus and D. Jeanteur for their help with the computer analysis of Tsx. We thank A. Middendorf for her expert technical assistance during the initial phase of the project and appreciate the discussions with $\mathrm{K}$. Heller and $\mathrm{H}$. Fsihi. We thank W. Boos for his support and are grateful to V. Koogle for her help in preparing the manuscript. Financial support for this study was provided by grants from the Deutsche Forschungsgemeinschaft and the Fonds der Chemischen Industrie.

\section{REFERENCES}

Altschul, S. F., Gish, W., Miller, W., Myers, E. W. \& Lipman, D. J. (1990). Basic local alignment search tool. J Mol Biol 215, 403-410.

Bachellier, S., Gilson, E., Hofnung, M. \& Hill, C. W. (1996). Repeated sequences. In Escherichia coli and Salmonella, pp. 2012-2040. Edited by F. C. Neidhardt. Washington, DC: American Society for Microbiology.

Benz, R. (1994). Uptake of solutes through bacterial outer membranes. In Bacterial Cell Wall, pp. 397-423. Edited by J.-M. Ghuyen \& R. Hakenbeck. Amsterdam: Elsevier Science Publishing.

Benz, R., Schmid, A., Maier, C. \& Bremer, E. (1988). Characterization of the nucleoside-binding site inside the Tsx channel of
Escherichia coli outer membrane. Reconstitution experiments with lipid bilayer membranes. Eur J Biochem 176, 699-705.

Birch, R. G., Pemberton, J. M. \& Basnayake, W. V. S. (1990). Stable albicidin resistance in Escherichia coli involves an altered outermembrane nucleoside uptake system. J Gen Microbiol 136, 51-58.

Bradley, D. E. \& Howard, S. P. (1992). A new colicin that adsorbs to outer membrane protein Tsx but is dependent on the tonB instead of the tolQ membrane transport system. J Gen Microbiol 138, 2721-2724.

Braun, G. \& Cole, S. T. (1984). DNA sequence analysis of the Serratia marcescens ompA gene: implications for the organization of an enterobacterial outer membrane protein. Mol Gen Genet 195, 321-328.

Bremer, E., Gerlach, P. \& Middendorf, A. (1988). Double negative and positive control of $t s x$ expression in Escherichia coli. $J$ Bacteriol 170, 108-116.

Bremer, E., Middendorf, A., Martinussen, J. \& Valentin-Hansen, P. (1990). Analysis of the $t s x$ gene, which encodes a nucleosidespecific channel-forming protein (Tsx) in the outer membrane of Escherichia coli. Gene 96, 59-65.

Carter, P., Bedouelle, H. \& Winter, G. (1985). Improved oligonucleotide site-directed mutagenesis using M13 vectors. Nucleic Acids Res 13, 4431-4443.

Casadaban, M. J. (1976). Transposition and fusion of the lac genes to selected promoters in Escherichia coli using bacteriophage Lambda and Mu. J Mol Biol 104, 541-555.

Cowan, S. W., Schirmer, T., Rummel, G., Steiert, M., Ghosh, R., Pauptit, R. A., Jansonius, J. N. \& Rosenbusch, J. P. (1992). Crystal structures explain functional properties of two $E$. coli porins. Nature 358, 727-733.

Dahl, M., Francoz, E., Saurin, W., Boos, W., Manson, M. D. \& Hofnung, M. (1989). Comparison of sequences from the malB regions of Salmonella typhimurium and Enterobacter aerogenes with Escherichia coli K-12: a potential new regulatory site in the interoperonic region. Mol Gen Genet 218, 199-207.

Dale, R. M. K., McClure, B. A. \& Houchins, J. P. (1985). A rapid single-stranded cloning strategy for producing a sequential series of overlapping clones for use in DNA sequencing: application to sequencing the corn mitochondrial 18S rDNA. Plasmid 13, 31-40.

Deng, W. P. \& Nickoloff, J. A. (1992). Site-directed mutagenesis of virtually any plasmid by eliminating a unique site. Anal Biochem 200, 81-88.

Elledge, S. J. \& Walker, G. C. (1985). Phasmid vectors for identification of genes by complementation of Escherichia coli mutants. J Bacteriol 162, 777-783.

Fsihi, H., Kottwitz, B. \& Bremer, E. (1993). Single amino acid substitutions affecting the substrate specificity of the Escherichia coli K-12 nucleoside-specific Tsx channel. J Biol Chem 268, 17495-17503.

Gerbl-Rieger, S., Peters, J., Kellermann, J., Lottspeich, F. \& Baumeister, W. (1991). Nucleotide and derived amino acid sequences of the major porin of Comamonas acidovorans and comparison of porin primary structures. J Bacteriol 173, 2196-2205.

Gerlach, P., Søgaard-Andersen, L., Pedersen, H., Martinussen, J., Valentin-Hansen, P. \& Bremer, E. (1991). The cyclic AMP (cAMP)-cAMP receptor protein complex functions both as an activator and as a corepressor at the $t s x-p_{2}$ promoter of Escherichia coli K-12. J Bacteriol 173, 5419-5430.

Hantke, K. (1976). Phage T6-Colicin K receptor and nucleoside transport in Escherichia coli. FEBS Lett 70, 109-112. 
Hofnung, M. (1995). An intelligent channel (and more). Science 267, 473-474.

Huang, H., Jeanteur, D., Pattus, F. \& Hancock, R. E. W. (1995). Membrane topology and site-specific mutagenesis of Pseudomonas aeruginosa porin OprD. Mol Microbiol 16, 931-941.

Huynh, T. V., Young, R. A. \& Davis, R. W. (1985). Constructing and screening cDNA libraries in $\lambda \mathrm{gt} 10$ and $\lambda \mathrm{gt} 11$. In $D N A$ Cloning, pp. 49-78. Edited by D. M. Glover. Oxford: IRL Press.

Inoue, T., Matsuzaki, S. \& Tanaka, S. (1995). Cloning and sequence analysis of Vibrio parabaemolyticus ompK gene encoding a $26 \mathrm{kDa}$ outer membrane protein, OmpK, that serves as receptor for broad-host-range vibriophage, KVP40. FEMS Microbiol Lett $134,245-249$.

Jeanteur, D., Lakey, J. H. \& Pattus, F. (1991). The bacterial porin superfamily: sequence alignment and structure prediction. Mol Microbiol 5, 2153-2164.

Jeanteur, D., Lakey, J. H. \& Pattus, F. (1994). The porin superfamily: diversity and common features. In Bacterial Cell Wall, pp. 363-380. Edited by J. R. Ghuysen \& R. Hakenbeck. Amsterdam: Elsevier Science Publishing.

Killmann, H., Benz, R. \& Braun, V. (1993). Conversion of the FhuA transport protein into a diffusion channel through the outer membrane of Escherichia coli. EMBO J 12, 3007-3016.

Kreusch, A. \& Schulz, G. E. (1994). Refined structure of the porin from Rhodopseudomonas blastica. Comparison with the porin from Rhodobacter capsulatus. J Mol Biol 243, 891-905.

Krieger-Brauer, H. J. \& Braun, V. (1980). Functions related to the receptor protein specified by the $t s x$ gene of Escherichia coli. Arch Microbiol 124, 233-242.

van der Ley, P., de Graaf, P. \& Tommassen, J. (1987). A comparative study on the $p h o E$ genes of three enterobacterial species. Implications for structure-function relationships in a pore-forming protein of the outer membrane. Eur J Biochem 164, 469-475.

Lucht, J. M., Boos, W. \& Bremer, E. (1992). Alignment of genes from the 9 minute region (araJ to tsx) of the Escherichia coli K12 linkage map to the physical map. J Bacteriol 174, 1709-1710.

Maier, C., Bremer, E., Schmid, A. \& Benz, R. (1988). Pore-forming activity of the Tsx protein from the outer membrane of Escherichia coli. Demonstration of a nucleoside-specific binding site. J Biol Chem 263, 2493-2499.

Maier, C., Middendorf, A. \& Bremer, E. (1990). Analysis of a mutated T6 receptor protein of Escherichia coli. Mol Gen Genet 221, 491-494.

Manning, P. A. \& Reeves, P. (1978). Outer membrane proteins of Escherichia coli K-12: isolation of a common receptor protein for bacteriophage T6 and colicin K. Mol Gen Genet 158, 279-286.

Michaelis, S. \& Beckwith, J. (1982). Mechanism of incorporation of cell envelope proteins in Escherichia coli. Annu Rev Microbiol 36, 435-365.

Miller, J. H. (1992). A Short Course in Bacterial Genetics. A Laboratory Manual and Handbook for Escherichia coli and
Related Bacteria. Cold Spring Harbor, NY: Cold Spring Harbor Laboratory.

Nikaido, H. (1994). Porins and specific diffusion channels in bacterial outer membranes. J Biol Chem 269, 3905-3908.

Pilsl, H. \& Braun, V. (1995). Novel colicin 10: assignment of four domains to TonB- and TolC-dependent uptake via the Tsx receptor and to pore formation. Mol Microbiol 16, 57-67.

Sambrook, J., Fritsch, E. F. \& Maniatis, T. (1989). Molecular Cloning: a Laboratory Manual, 2nd edn. Cold Spring Harbor, NY: Cold Spring Harbor Laboratory.

Sanger, F., Nicklen, S. \& Coulson, A. R. (1977). DNA sequencing with chain-terminating inhibitors. Proc Natl Acad Sci USA 74, 5463-5467.

Schirmer, T., Keller, T. A., Wang, Y.-F. \& Rosenbusch, J. P. (1995). Structural basis for sugar translocation through maltoporin channels at $3 \cdot 1 \AA$ resolution. Science 267, 512-514.

Schneider, H., Fsihi, H., Kottwitz, B., Mygind, B. \& Bremer, E. (1993). Identification of a segment of the Escherichia coli Tsx protein that functions as a bacteriophage receptor area. J Bacteriol 175, 2809-2817.

Sprenger, G. A. \& Lengeler, J. W. (1984). L-Sorbose metabolism in Klebsiella pneumoniae and Sor $^{+}$derivatives of Escherichia coli K12 and chemotaxis toward sorbose. J Bacteriol 157, 39-45.

Struyvé, M., Moons, M. \& Tommassen, J. (1991). Carboxyterminal phenylalanine is essential for the correct assembly of a bacterial outer membrane protein. J Mol Biol 218, 141-148.

Takeshita, S., Sato, M., Toba, M., Masahashi, W. \& HashimotoGotoh, T. (1987). High-copy-number and low-copy-number plasmids for lac $Z \alpha$-complementation and chloramphenicol- or kanamycin-resistance selection. Gene 61, 63-74.

Valentin-Hansen, P., Søgaard-Andersen, L. \& Pedersen, H. (1996). A flexible partnership: the CytR anti-activator and the cAMPCRP activator protein, comrades in transcriptional control. $\mathrm{Mol}$ Microbiol 20, 461-466.

Way, J. C., Davis, M. A., Morisato, D., Roberts, D. E. \& Kleckner, N. (1984). New Tn10 derivatives for transposon mutagenesis and for construction of $l a c Z$ operon fusions by transposition. Gene 32, 369-379.

Weiss, M. S., Kreusch, A., Schiltz, E., Nestel, U., Welte, W., Weckesser, J. \& Schulz, G. E. (1991). The structure of porin from Rhodobacter capsulatus at $1.8 \AA$ resolution. FEBS Lett 280 , 379-382.

Werts, C., Charbit, A., Bachellier, S. \& Hofnung, M. (1992). DNA sequence analysis of the lamB gene from Klebsiella pneumoniae. Implications for the topology and the pore functions in maltoporin. Mol Gen Genet 233, 372-378.

Zalkin, H. \& Nygaard, P. (1996). Biosynthesis of purine nucleotides. In Escherichia coli and Salmonella, pp. 561-579. Edited by F. C. Neidhardt. Washington: American Society for Microbiology.

Received 29 August 1996; accepted 30 September 1996. 